\title{
Effect of probiotics supplementation on acute diarrhea in infants: a randomized double blind clinical trial
}

\author{
I Gusti Ngurah Sanjaya Putra, Sudaryat Suraatmaja, I Ketut Nomor Aryasa
}

\begin{abstract}
Background Probiotics has advantages as a supplement for management of infants with acute diarrhea. It influences the duration of diarrhea by enhancing immune responses, elaborates antimicrobial substances and occupies intestinal mucosal sites, inhibits the attachment and the growth of pathogenic organisms by achieving competitive exclusion and microbial balance.

Objective To assess the clinical effects of probiotics supplementation on acute diarrhea in infants.

Methods This was a double blind, randomized clinical controlled trial performed on infants aged 1-12 months old with acute diarrhea, hospitalized in Sanglah Hospital, Denpasar. Subjects were divided into two groups; the treatment group had standard management with adjuvant probiotics, while the control group received standard management with placebo.

Results From 70 infants enrolled in this study, the mean duration of diarrhea in treatment group was significantly shorter than that in the placebo group, 49.03 hours (SE 3.09) $(95 \% \mathrm{CI} 42.98 ; 55.08)$ vs 73.03 hours (SE 3.28) (95\%CI 66.61;79.45); $\mathrm{P}=0.001$. Regarding failure of the treatment, probiotics supplementation had relative risk reduction (RRR) of $67 \%$ and absolute risk reduction (ARR) of $57 \%$. In multivariate cox regression analysis it was found that only probiotics supplementation influenced the duration of acute diarrhea in infants.

Conclusion Probiotics can shorten the duration of acute diarrhea, and is safe as an adjuvant to standard management for infants with acute diarrhea.[Paediatr Indones 2007;47:172-178].
\end{abstract}

Keywords: Acute diarrhea, probiotics, duration of diarrhea

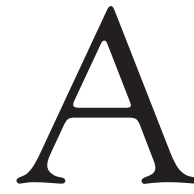

cute diarrhea is one of the main causes of children morbidity and mortality in developing countries, including Indonesia. ${ }^{1,2}$ Based on the National Heath Surveilance in the year 2001, diarrhea ranks the $3^{\text {rd }}$ cause of mortality in infants and the $2^{\text {nd }}$ cause of mortality in children under five years old, which is 2.3 of every 1,000 children under five years old. ${ }^{3}$ In our pediatric outpatient clinic in Sanglah hospital, Denpasar, in 1999, there were 923 children came with diarrhea. This was the $4^{\text {th }}$ top reason of outpatient visit. $^{4}$

Approximately 90\% children with acute diarrhea are treated successfuly using oral rehydration strategy and nutritional diet. However, oral rehydration strategy does not significantly reduce the volume, frequency and duration of diarrhea. Based on the above reasons, an effort is made to find an effective, affordable, and costless supplement that can be given together with standard acute diarrhea treatment in order to reduce the duration of diarrhea. Probiotics

From The Department of Child Health, Medical School, Udayana University, Sanglah Hospital, Denpasar, Bali, Indonesia.

Reprint requests to: I Gusti Ngurah Sanjaya Putra, MD, Department of Child Health, Medical School, Udayana University, Sanglah Hospital, Jl. Pulau Nias, Denpasar, Bali, Indonesia. Tel/Fax. 62-361-244038. E-mail: ika_unud@yahoo.com. 
supplementation with the dose of $10^{7}$ given twice daily for five days has proven to give benefits in reducing the frequency, severity, or duration of diarrhea. ${ }^{5-7}$ The objective of this study was to determine the effect of probiotics supplementation on the duration of acute diarrhea in infants.

\section{Methods}

This study was a double blind randomized clinical trial, conducted at Gastroenterology Subdivision, Department of Child Health, Medical School, Udayana University, Sanglah Hospital, Denpasar, from June to October 2004. Eligible patients were chosen using consecutive sampling. The study has been approved by the Ethical Clearance from the Ethics Commitee of Medical School, Sanglah Hospital, Denpasar, and an informed consent was obtained from parents.

The inclusion criteria were patients with mild to moderate dehydration due to acute diarrhea, aged 1-12 months old, and duration of diarrhea before hospitalization was equal to or less than two days. Infants with complicated diarrhea or diarrhea with complication, or had been treated with symptomatic treatment for diarrhea, or had been given formula milk and drugs, or had probiotics contained food or the parents refused to participate in the study, were excluded.

Acute diarrhea was defined as the defecation frequency of more than three times/day or more than usual habit accompanied by changes in feces consistency, with or without blood and or mucous, lasting for less than seven days. ${ }^{1,8}$ Recovery time was the time needed until the frequency of defecation was equal to or less than three times/day with normal stool consistency without any complication. ${ }^{1,8}$ Diarrhea with complication was defined as diarrhea episode accompanied by direct effect of acute diarrhea such as severe dehydration, metabolic acidosis, seizure, and ileus paralytic. ${ }^{9}$ Complicated diarrhea was defined as acute diarrhea with severe malnutrition, severe dysenteries, and other diseases such as congenital disorders of gastrointestinal tract, respiratory infection, anemia, vitamin A deficiency, immunocompromised condition, congenital heart disease, and other systemic diseases. ${ }^{9}$ Dehydration status was assessed according to the WHO standard, ${ }^{9}$ while nutritional status was determined based on $\mathrm{Z}$ score of weight for length.

Patient who did not take neither oral probiotic nor placebo in $1 \times 12$ hours and discharged by requests was considered as drop-out cases. Patients with failure of treatment were defined as patients who failed to recover on day five of treatment or those who experienced any complication before day five, or had co-infection or adverse events affecting the duration of diarrhea, or patients who passed away.

A questionnaire was used to record the baseline characteristics of clinical and laboratory data, duration of diarrhea in the hospital, frequency of defecation, consistency of feces, complications and adverse events.

Total study subjects was 70 infants. They were randomized into two groups; the treatment group had standard diarrhea therapy with probiotic supplement while the control group received standard diarrhea therapy with placebo. The randomisation process was done with 6-block randomization, and the codes were kept in closed envelopes. The envelopes were kept at PT Novell Pharmaceutical Laboratories and opened there after the study finished.

All subjects were managed according to the standard therapy recommended by WHO for acute diarrhea, with rehydration. Routine examination of the stool was performed to determine specific cause of diarrhea. Antibiotics were given if we found leukocyte $\geq 10 /$ field in the feces. All medicines prescribed before admission was stopped.

One sacchet of probiotics contained Lactobacillus acidophilus, Bifidobacterium longum, Streptococcus faecium viable cell $>1 \times 10^{7} \mathrm{CFU} / \mathrm{g}$, vitamin $\mathrm{C} 10 \mathrm{mg}$, vitamin $B_{1} 0.5 \mathrm{mg}$, vitamin $B_{2} 0.5 \mathrm{mg}$, vitamin $B_{6} 0.5$ $\mathrm{mg}$, and niacin $2 \mathrm{mg}$. Infants in the treatment group received two sacchets daily. Placebo contained vitamin only, with similar taste, appearance and bottle, were coded and supplied by PT Novell Pharmaceutical Laboratories.

All study subjects were followed-up until they recovered. To assess the outcome, we performed evaluation and measurement of dehydration status, frequency of defecation, stool consistency, adverse events and complications every six hours, while evaluation and measurement of body weight, compliance of taking probiotics and placebo, were done every 24 hours. In this study, drop out and treatment failure rates were accepted if the rate was 
bellow 20\%. Subjects which were considered as drop out cases or treatment failures were analyzed with the worst assumption to intention to treat analysis. Study prosedures are shown in Figure 1.

Data were analyzed using SPPS Window 11.5 software. The difference of mean of recovery time was tested using student's t test. Additional variables (complications or adverse events on study duration) were analyzed using $\mathrm{x}^{2}$ test. The primary outcome result was the difference of duration of diarrhea between two groups, showed by Kaplan-Meier curve. Differences in duration of diarrhea between two groups were tested using log-rank test. Risk of treatment failure between those two groups was compared with relative risk reduction (RRR) and absolute risk reduction (ARR). We made adjustment on external variables to duration of diarrhea between two groups using cox-regression analysis. $\mathrm{P}$ value of $<0.05$ with $95 \%$ confidence interval were considered as statistically significant.

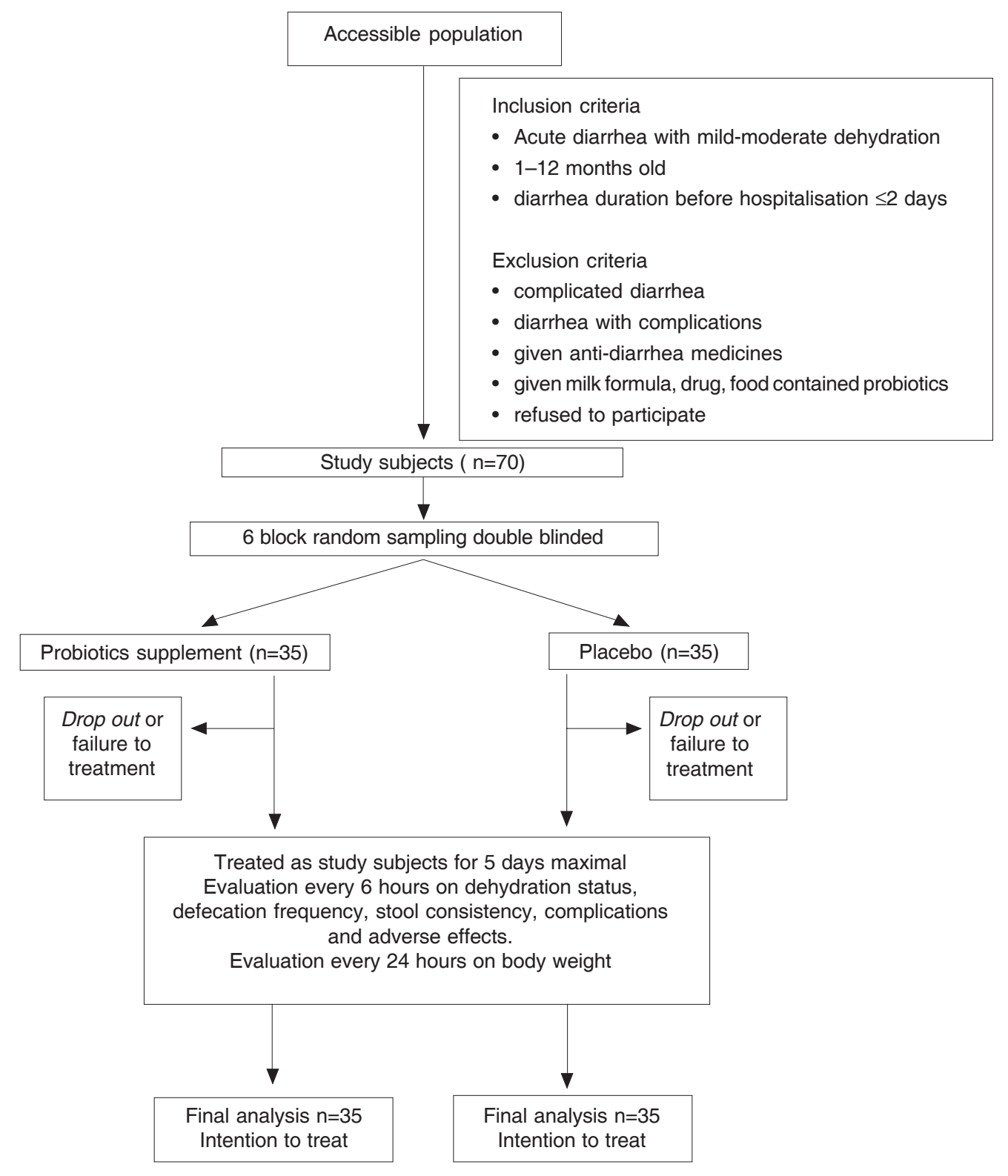

Figure 1. Flow chart of the study procedure 


\section{Results}

During the study period, there were 144 infants aged 1-12 months old admitted to Sanglah Hospital due to acute diarrhea. Seventy infants were eligible to the study, while 74 infants that were ineligible to the study, consisted of 61 infants with acute diarrhea accompanied with other problems or co-infections (one infant had severe malnutrition, 10 infants had bronchopneumonia, two infants had anemia, 19 infants had acute rhinopharingitis, 21 infants had acute tonsilopharyngitis, three infants had acute otitis media, and five infants had acute bronchiolitis), five infants were given formula milk, drug and food contained probiotics, two infants had been treated using symptomatic diarrhea therapy, and six infants refused to participate in the study.

Mean age of infants in treatment group was 7.60 (SD 4.01) months while that in the control group was 7.80 (SD 3.64) months. There were four infants aged 1-6 months who were exclusively breastfed in the treatment group and three infants in the control group. Baseline characteristics of those two groups are shown in Table 1.

Table 1. Baseline characteristics of infants with acute diarrhea in treatment and control groups

\begin{tabular}{lcc}
\hline Characteristics & $\begin{array}{c}\text { Treatment } \\
\text { group } \\
(\mathrm{n}=35)\end{array}$ & $\begin{array}{c}\text { Control } \\
\text { group } \\
(\mathrm{n}=35)\end{array}$ \\
\hline Age (month), mean (SD) & $7.60(4.01)$ & $7.80(3.64)$ \\
Sex & 20 & 16 \\
$\quad$ Boys & 15 & 19 \\
Girls & $7279(2106)$ & $7619(2145)$ \\
IBW(gram), mean (SD) & & \\
Nutritional status & 33 & 32 \\
Good & 2 & 3 \\
$\quad$ Moderate malnutrition & 4 & 3 \\
Diet intake & 1 & 2 \\
Breast feeding & 3 & 6 \\
Formula & 3 & 3 \\
BF + Formula & 13 & 13 \\
BF+Formula+milk porridge & 11 & 8 \\
BF + milk porridge & & \\
Formula + milk porridge & $38.91(10.83)$ & $33.54(12.47)$ \\
Pre-hospital diarrhea \\
(hours),mean (SD)
\end{tabular}

Reduction in frequency of defecation to equal or less than three times/day was significantly faster in the treatment group compared with that in control group $\{47.37$ hours (SD17.79) vs 67.20 hours (17.79) with mean difference of 20.22 (95\%CI 10.98;29.46); $\mathrm{P}=0.001\}$. Stool consistency was firmer at shorter duration in the treatment group, with significant statistical difference $\{45.31$ hours (SD 21.35) vs 70.45 hours (SD 21.35) with mean difference of 25.54, (95\%CI 16.06;35.02); $\mathrm{P}=0.001\}$.

Mean duration of diarrhea as a primary results was significantly shorter in the treatment group compared to that in control group $\{49.03$ hours (SE 3.09) $(95 \%$ CI $42.98 ; 55.08)$ vs 73.03 hours (SE 3.28) (95\%CI 65.61;79.45); $\mathrm{P}=0.001\}$. Based on Kaplan Meier analysis, duration of diarrhea was significantly shorter in treatment group compared to that in control group (log rank test, $\mathrm{P}=0.001$ ). Primary outcome is showed on Figure 2.

During our study, two infants in the control group had treatment failure, one patient was cured on study day five, the other one infant got bronchopneumonia on the second day of study. There were two infants, one in control group and one in treatment group, considered as drop out cases. The differences of treatment failure between two groups were expressed as RRR of $67 \%$ and ARR of $57 \%$.

In this study, there were no significant difference in the body weight gain between treatment and control groups at the time of admission and discharged from

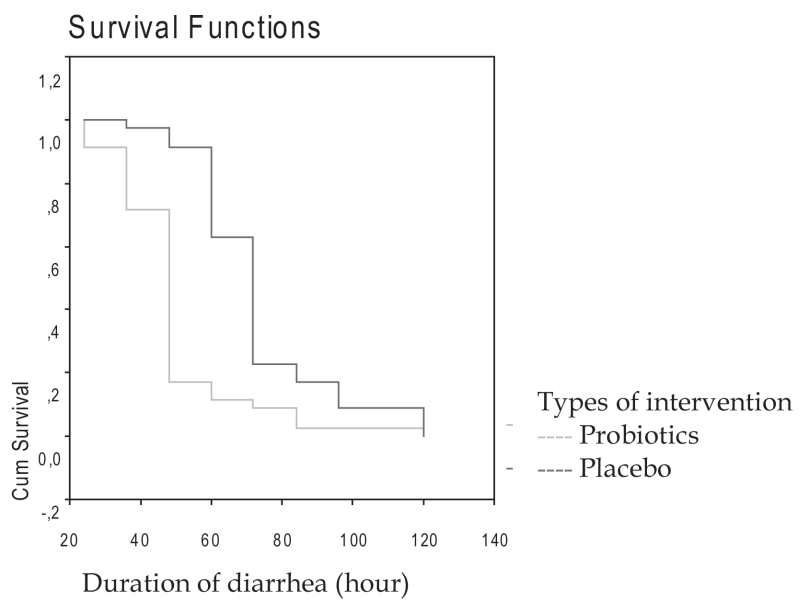

Figure 2. Kaplan - Meier survival curve of duration of diarrhea in the treatment group and control group on day 5 of study 
hospital $\quad\{0.43(\mathrm{SD} 0.31)$ vs 0.32 (SD 0.15); mean difference was $-0.16(95 \% \mathrm{CI}-0.22 ; 0.012) ; \mathrm{P}=0.79\}$.

From multivariant analysis, it was proven that only probiotics supplementation (cox regression, $\mathrm{P}=0.001$ ) affected the duration of diarrhea (Table 2).

In this study, we found no adverse events caused by probiotics supplementation.

\section{Discussion}

Probiotics as a supplement for acute diarrhea standard therapy was proven to give benefits in reducing the severity of clinical manifestations and the duration of acute diarrhea. ${ }^{5-7,10-12}$ Meta analysis study in probiotics for invasive and non invasive diarrhea done by Saavedra et $\mathrm{al}^{13}$ showed significant results in 12 out of 15 studies and in 11 out of 15 studies, respectively.

The recovery time in the treatment group was shorter compared to that in placebo group, and the difference were statistically significant. Based on those two parameters assessment, we found that the duration of diarrhea in treatment group was shorter compared to that in the placebo group, 49.03 hours vs 73.03 hours. Our results were similar with those of Simakachorn et al. ${ }^{14}$ The similar results were also reported by Shornikova et al. ${ }^{15}$ Guandalini et al ${ }^{16}$ examined children aged 1-36 months old with acute diarrhea, using LGG $10^{10}$ twice daily for four to six days, and they found that the duration of diarrhea were 58 hours in probiotics group compared to 72 hours in placebo group. Shornikova et $\mathrm{al}^{17}$ in their study on children between
6-36 months old with acute diarrhea, using Lactobacillus reuteri $10^{10-14}$ single dose daily for five days, found that the duration of diarrhea in the treatment group was shorter compared to that in the placebo group, 40 hours vs 69 hours. Nisa Tri Rini et al ${ }^{18}$ in their study on children aged 1-60 months using Lactobacillus, found that in the treatment group, the duration of diarrhea was 26 hours shorter compared to that in the placebo group. Meta analysis study done by Van Niel CW et $a^{19}$ showed that probiotics are safe and effective for acute diarrhea in children. All studies on diarrhea showed that probiotics supplementation was considered to give benefits in reducing the duration of diarrhea, and in reducing the chance to become chronic diarrhea. Probiotics as a supplement to acute diarrhea management in infants give many advantages in influencing the duration of diarrhea by enhancing immune response, elaborating antimicrobial substances, and intestinal mucosal sites, inhibiting the attachment and growth of pathogenic organisms by achieving competitive exclusion and microbial balance.

In our study we found that probiotics supplementation reduced treatment failure as big as 67\% (RRR $67 \%$ ) and it was successfully used as treatment with ARR 57\% compared with placebo group.

Using Covarian analysis (Cox-regression), we found that duration of diarrhea was only affected significantly by probiotics supplementation, while other factors such as age, nutritional status, prehospital diarrhea duration, medicine before admission, spesific caused on stool, and nutritional intake had no significant effects.

Table 2. Inter-variables connection that affected acute diarrhea duration in treatment group vs control group

\begin{tabular}{lccccc}
\hline \multicolumn{1}{c}{ Free variables } & B & S E & P & Exp (B) & $95 \%$ Cl for Exp (B) \\
\hline Age & -0.023 & 0.05 & 0.64 & 0.98 & $0.89 ; 1.07$ \\
Diet intake & & & & & \\
$\quad$ - Breast feeding & -0.01 & 0.54 & 0.98 & 0.99 & $0.34 ; 2.88$ \\
$\quad$ - Formula & -0.24 & 0.77 & 0.76 & 0.79 & $0.17 ; 3.58$ \\
- BF+ formula & -0.87 & 0.54 & 0.11 & 0.42 & $0.14 ; 1.21$ \\
$\quad$ - BF + formula + MP & -0.27 & 0.50 & 0.58 & 0.76 & $0.29 ; 2.02$ \\
$\quad$ - Formula + MP & -0.10 & 0.33 & 0.76 & 0.90 & $0.47 ; 1.74$ \\
Nutrional status & -0.15 & 0.49 & 0.76 & 0.86 & $0.33 ; 2.24$ \\
Pre-hospital diarrhea duration & -0.00 & 0.01 & 0.76 & 1.00 & $0.97 ; 1.02$ \\
Antibiotics before admission & 0.46 & 0.38 & 0.23 & 1.59 & $0.75 ; 3.36$ \\
Spesific caused on stool & 0.09 & 0.53 & 0.86 & 1.10 & $0.39 ; 3.11$ \\
Probiotics & -1.17 & 0.29 & 0.001 & 0.31 & $0.17 ; 0.55$ \\
\hline
\end{tabular}

$\mathrm{B}=$ coeficient of Cox regression; $p=$ probability; $\operatorname{Exp}(\mathrm{B})=$ Odds Ratio; $95 \% \mathrm{Cl}=$ confident interval $95 \%$ $\mathrm{MP}=$ milk porridge 
I Gusti Ngurah Sanjaya Putra et al: Effects of probiotics in infants with acute diarrhea

Body weight gain at the recovery time was not statistically significant different between the treatment and placebo groups. In our study, we did not find any adverse events due to probiotics supplementation. To maintain the study validity, we performed intention to treat analysis, we analysed the drop out subjects and failure to treatment by taking the worst assumption of treatment.

Our study has several limitations. We did not examine stool culture so we could not determine the enteric pathogen as the cause of diarrhea. In conclusion, probiotics supplementation in addition to the standard diarrhea therapy in infants with acute diarrhea gives benefits in reducing duration of diarrhea.

\section{Acknowledgements}

Thanks to PT. Novell phamaceutical Laboratories for the contribution in probiotics and placebo supply. Gratitude and thanks to all paramedical and pediatric division staff in Sanglah hospital Hospital for their cooperation and help in this study and special thanks and gratitude to all patients and their parents for their willingness to participate in this study. We realized that without their contribution it would be imposible to perform this study.

\section{References}

1. Suraatmaja S. Kapita selekta gastroenterologi: Diare akut. Denpasar: SMF IKA FK UNUD; 2002. p. 1-24.

2. Irwanto, Abdul Rohim, Subijanto Marto Sudarmo. Diare akut pada anak. In: Soegeng Soegijanto, editor. Ilmu penyakit anak diagnosa dan penatalaksanaan. $1^{\text {st }}$ ed. Jakarta: Salemba Medika; 2002. p. 73-8.

3. Profil kesehatan Indonesia 2001, 2002. Departemen Kesehatan Republik Indonesia, Jakarta. Cited 2004 Oct 4. Available from: url: http// www. Depkes.go.id.

4. Departemen Kesehatan RI. Epidemiologi dan etiologi diare. In : Buku ajar diare. Jakarta: Departemen Kesehatan RI, Direktorat Jendral Pemberantasan Penyakit Menular dan Penyehatan Lingkungan Pemukiman (Ditjen P2M \& PLP); 1995. p. 3-136.

5. Subijanto Marto Sudarmo, Reza Gunadi Ranuh. Peranan prebiotik dan probiotik dalam upaya pencegahan diare pada anak. Presented at Continuing Education XXX. Lab IKA FK UNAIR/RSUD Dr. Soetomo-IDAI Cabang Jawa Timur. Surabaya, July 30, 2000.
6. Abdul Rohim, Subijanto Marto Sudarmo. Probiotik dan flora normal usus. In: Soegeng Soegijanto, editor. Ilmu penyakit anak diagnosa dan penatalaksanaan. $1^{\text {st }}$ ed. Jakarta: Salemba Medika; 2002. p. 93-101.

7. Rolfle RD. The role of probiotic cultures in the control of gastrointestinal health. Presented at Symposium: Probiotic Bacteria implications for human health. American Society Nutritional Sciences. Washington, April 17-21, 2000.

8. Pitono Soeparto, Liek S Djupri, Subijanto Marto Sudarmo. Gangguan absorpsi sekresi, sindroma diare. $2^{\text {nd }}$ ed. Surabaya: Gramik; 1999. p. 37-76.

9. Noerasid H, Suraatmaja S, Asnil PO. Gastroenteritis (Diare) akut. In: Suharyono, Boediarso A, Halimun, editors. Gastroenterologi anak praktis. Jakarta: Balai Penerbit FK UI; 1988. p. 51-96.

10. Agus Firmansyah. Terapi Probiotik dan prebiotik pada penyakit saluran cerna anak. Sari Pediatri 2001;2:210-3.

11. Isolauri E, Juntunen M, Rautanen T, Silanaukee P, Koivula T. A human lactobacillus strain (lactobaccillus casei sp strain GG) promotes recovery from acute diarrhea in children. Pediatrics 1991;88:90-7.

12. Bernet MF, Brassart D, Neeser JR, Servin AL. Lactobacillus acidophillus LA 1 binds to cultured human intestinal cell lines and inhibits cel attachment and cell invasion by enterovirulent bacteria. Gut 1994;35:483-9.

13. Jose M Saavedra, Adel Abi-Hanna. Clinical Studies of Probiotic Agent. In: Hanson LA, Yolken RH, editors. Probiotics other nutritional factor, and intestinal mikroflora. Philadelphia: Nestec Ltd; 1999. p. 271-86.

14. Simakachorn N, Pichaipat V, Rithipompaisam P, Kongkaew C, Tongpradit P, Varavithya W. Clinical evaluation of addition of lyophilized, heat killed lactobacillus acidophilus LB to oral rehydration therapy in the treatment of acute diarrhea in children. J Pediatr Gastroenterol Nutr 2000;30:68-72.

15. Shornikova AV, Isolauri E, Burkanova L, Lukovnikova S, Vesikari T. A trial in the Karelian Republic of oral rehydration and lactobacillus GG for treatment of acute diarrhea. Acta Pediatr 1977;86:460-5.

16. Guandalin S, Pensabene L, Zikri MA. Lactobacillus GG administered in oral rehydration solution to children with acute diarrhea: A Multicenter European Trial. J Pediatr Gastroenterol Nutr 2000;30:54-60.

17. Shornikova AV, Casas IA, Isolauri E, Mykkanen H, Vesikari T. Lactobacillus reuteri as a therapeutic agent in acute diarrhea in young children. J Pediatr Gastroenterol Nutr 1977;24:399-401.

18. Nisa Tri Rini, Rusdi Ismail, Achirul Bakri, Prambudi R. The influence of lactobacillus on duration and frequency of acute diarrhea in the pediatric in patient M.Hoesin Hospital. 
I Gusti Ngurah Sanjaya Putra et al: Effects of probiotics in infants with acute diarrhea

Presented at $12^{\text {th }}$ National congress of child health and $11^{\text {th }}$ Asean pediatric federation coference. June 30 - July 4, 2002.Denpasar (Abstract).
19. Van Niel CW, Feudtner C, Garrison MM, Christakis DA. Lactobacillus therapy for acute infectious diarrhea in Children: A Meta-analysis. J Pediatr 2002;109:34-8. 